\title{
The Knowledge Business: Economic Issues of Access to Bibliographic Information
}

\section{Carlton Rochell}

Current technologies, many of which are based on computers, are creating a knowledge industry. One feature of this development is a growing tendency to treat information as a commodity. In private industry this means that a dollar value is attached. This practice causes difficulties for librarianship, since information has historically been offered freely. The imposition of fee-based services may radically curtail the breadth of resources conveniently available to our citizenry. This article explores such issues, and the author urges careful examination of the alternatives before imposing fees. Libraries need to devise innovative strategies in order to protect traditional rights of entitlement to information. This may require librarians to develop cooperative arrangements with the private sector and to use the collective influence of libraries to lower the rates charged by that sector for online and other similar services.

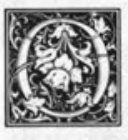

gden Nash once wrote, "Certainly there are lots of things in life that money won't buy, but it's very funny-have you ever tried to buy them without money?"'1 Most of us have been taught that knowledge is one of those things money can't buy. But, when you consider the cost of tuition, journals, books, reference materials, and the new electronic media, you suddenly realize that we do indeed buy knowledge. To some extent, we always have. The difference today is one of cost, not of kind.

There have always been those who could not afford to pay the price of knowledge. They have traditionally turned to libraries, because one of our missions has been to provide free access to information. Today, that mission seems imperiled, for librarians are asking if we can continue to play this role in the new information age and if we can supply access not only to books and periodicals but to all the sources of information today's technology is making available, technology that we are hard-pressed to afford.

This technology is creating a knowledge industry. What we must determine-and determine quickly -is what role libraries should and can play in this industry. Or, as I would prefer to state the issue, how can we sustain our traditional role in this new environment?

In this environment, the most powerful players of the moment appear to be the database vendors-the public, quasipublic, and private developers of databases. But our own quasi-public databases, those developed by library networks, for example, OCLC, RLIN, WLN, and the Library of Congress public database, occupy a small and relatively inconspicuous corner of the new world of electronic networks. The fastest-growing elements are commercial information services such as The Source and Compuserve, government databases, and the growing number of publishers' databases and specialized services. It is hardly surprising, since we now have a knowledge 
industry, that the concept of "information as a commodity" should have gained such currency.

Of course, information has always been somewhat of a commodity. Publishers have been selling it for years. Yet, we have tended to think of information as free, allowing that books were private property while their contents were somehow public property. But even if we think of information as "free" we pay for its transmission in forms that please us or are convenient to use. We buy books, magazines, and specialized journals. Today, however, some information exists only in a form for which we must pay, like the contents of certain newsletters.

Although the commodification of information may begin with payment for transmission in a particular format, it does not end there. As more and more information becomes available through bibliographic databases and document delivery networks, less will be available in other forms. In time, we will no longer be paying for the transmission of information. We will be paying for information itself, in the only form in which we can find it. It will no longer be only the specialized products of newsletters to which free access is denied.

Let's look at a concrete example of the commodification of information. Before 1980, all the findings of the nation's decennial census were available in print. The bound volumes were available in any federal book depository. But significant portions of the 1980 census exist only in computer files. It is available, but there is no way to gain access to it except by computer. And there are few places where computer time is free.

John R. U. Page goes further in explaining how technology will alter the economics of access to information. We now pay for the processes by which "the computer and retrieval system selects only relevant information from the total mass," and for the information itself. ${ }^{2}$ Moreover, Page points out, "the user is required to pay to look at it to judge its relevance. ${ }^{\prime 3} \mathrm{He}$ identifies this as "a relatively new commercial principle not too far applied in other sections of the information industry, for example, bookshops and bookstalls., ${ }^{\prime 4}$ And,
I might add, it is also not applied in other industries. Imagine paying for the right to look-just look-at Ford's 1984 models.

As a commodity, information is unique. It is not private goods like a car. The owner of information still has it even after it is sold. Neither is it a commodity that exists in limited supply. Information can be used without being used up. Forty people can pay for connect time to the New York Times databank and search for information on, for example, the first moon walk, and that same information will still be available for any number of future queries. This may cause us to wonder just why database vendors have established a pricing structure that tends to limit rather than expand demand. It should make us ask if the prices that libraries or their users pay for line charges or connect time are an equitable or economical way of selling to bulk purchasers of database services. Moreover, we must recognize that if information is a commodity, then it is a peculiar one: it is not a commodity alone, but also an entitlement. This is how the library world has tended to view information, and this is not a perspective we should abandon. The idea that access to information should be governed by laws of equity, and not economics, came through loud and clear at the White House Conference on Library and Information Services in 1979. For most of us, it remains an article of faith that people should not have to pay for access to public information.

Nancy Kranich offers a persuasive explanation of why the services that libraries offer are public entitlements that must remain cost-free in order to serve the public good:

Libraries offer goods and services that provide external benefits to society at large. If priced, these services would probably not be consumed at levels in line with the long-term public interest. In conjunction with the educational process, library services provide important collective benefits that result in increased national income, wealth, and social welfare. In addition, libraries offer the public the 'demand option' to use materials, should the need arise at a particular future time. Finally, libraries offer services to poor and wealthy alike, thereby assuring access to information resources on an equitable basis. $^{5}$ 
It might also be added that there has been a quantum leap in the amount of information people must have to participate fully, as consumers or producers, in our economy. To be an effective citizen today requires a fairly sophisticated understanding of science and economics as well as an appreciation of other cultures.

Given the public's need for information as a tool for survival, personal achievement, and cultural enhancement, it seems obvious that information must be widely available. To insure that it is, information is best provided on a collective, rather than an individual, basis. Few would argue with this. But if we persist in our notions of meeting today's information needs and of assuring equitable access, we run squarely into the issue of cost. Who will pay for individual access to information available only via the new technology? We must grapple with, but not necessarily surrender to, the notion of user fees.

It can be and has been argued that user fees amount to double charges, because the public pays for library service through taxes and students pay through tuition. The case has also been made that levying user fees in libraries imposes a form of censorship that results in the acquisition of only those materials or databases for which people are willing to pay. As Fay Blake has argued, "no matter what your analysis of the needs of your whole community may reveal, no matter how useful a service may be, no matter how effectively your library's resources can be organized to provide a service, the ultimate test for development of services will not be the needs of society but the ability and desire of a relatively few individual users to pay for it. ${ }^{\prime \prime 6}$ Because the most profitable databases available are those in business and science, the databases that are in greatest jeopardy are those in the humanities and social sciences. Thus, if user fees are imposed as the norm and the marketplace prevails, the breadth of resources available will be radically curtailed.

This argument meshes well with another concern we should have about imposing user fees for electronic services, that is, the difficulty of finding where to draw the line. We might well be opening the door to "fee for service" libraries. If we demonstrate that one service can be self-sustaining, why not all services? Why not charge students by the number of books they use as well as the amount of time they spend online? These are questions we cannot answer philosophically. Practical answers may become equally difficult, once we take it upon ourselves to break with our tradition of free access with nominal fees imposed only as a means of assuring the availability of scarce resources, for example, fees for late returns or interlibrary loans.

Nevertheless, there are voices calling loudly for user fees. They argue that our commitment to equitable access is without a basis in reality. After all, libraries serve only a small part of the nation's public, and most users are in the middle or upper class. Therefore, they conclude, libraries are not worthy of public support. Why should the poor be taxed for a middleclass service? To them, the important question now seems to be not "fee or free, but how much to charge.'

Indeed, one must search diligently to find a library that has not already skewed our basic professional philosophy when it comes to database searching. Ibelieve that it is too easy to ask "how much" and too few of us have taken the time to consider "how else." Undoubtedly, libraries must change to meet the demands of a wired world, but they can change their technology, even their methods, without changing their mission. Libraries benefit the whole of society, directly and indirectly. Many of our nation's best writers first discovered literature from inside a public library. It is clear that libraries play a vital role in educating citizens by providing them with the option to learn and in developing citizens who can contribute to our culture.

Larry White argues that even if libraries constitute a "government service," there is no reason why they should not operate on a fee basis. He points out that fees are levied for other government services such as toll roads and municipal parking lots. ${ }^{8}$ That is true. But government charges for parking space, like fees at municipal ten- 
nis courts, are meant to ration limited facilities and ones to which there are alternatives. Many localities also charge a minimal fee for water. But what do you suppose the reaction would be if the townfolk suddenly discovered that some of their neighbors were literally dying of thirst because they could not afford to pay the local water rates? Or what if we were charged by the glass? In the case of access to information, the victims who are unable to tap in because they cannot afford the fee would not even be aware of the vital resources they were being denied.

We saw what happened not long ago when the National Library of Medicine raised access fees to Medline. Use by doctors fell off sharply. One shudders to think of what this may have cost the doctors concerned or their patients. Although Medline use picked up later when the price was lowered, the volume of queries never returned to its earlier level.

User fees are an easy answer to a hard question, but they should not be used as an excuse for librarians to abandon their traditional commitments. Instead, we should consider how else to deal with the costs of our new information systems. We must look closely at how we automate our libraries. What will the new technology mean in terms of acquisitions? What benefits can we expect to derive from the new systems and how can we best use them? How can our public get the most out of the services we will be providing? How should we negotiate for a new understanding of library services and for a more substantial role within the information industry?

Consider first how management can increase the cost benefits of automation by looking from a more systematic perspective at the electronic library. For example, there are various levels of automation within New York University's libraries. At the local level, there is a computerized circulation/reserve system, an information management system, and an online cata$\log$. These systems will communicate with each other through a local area network. This first-level node is connected to a regional consortium and directly linked to RLIN, a national network. Each level op- erates alone and within a larger system.

In moving through these various levels, library administrators should remember several points. The first, so obvious that it is rarely mentioned, is to make certain that their organizations are running efficiently regardless of automation. The second is to never jump the gun. We all like to think that we are above "keeping up with the Joneses, "' but there is considerable pressure to develop something like an online catalog when it starts to appear that "everybody has one but us." Yet it is unrealistic to think that we can all be at the same stage of development at the same time. It does not pay to try to implement a system for which you are not ready. Library administrators must also be wise in drawing up contracts. A good contract with a responsible vendor can be powerful insurance against the kinds of technological failure that plunge you into a financial crisis.

Keep in mind that it makes economic sense to budget for technology on a capital basis by spreading the cost over several years and providing a means to cover depreciation. Further, administrators must pay attention to how the new technology is being used by both staff and patrons. One of the best ways to drive down costs is to recognize when and why a system or a product is not working effectively. If online searches cost too much, searchers may not be using the system properly or the system itself may not be "user friendly."

For some libraries, it may be useful to set search/cost parameters. James Rice, Jr., notes:

At Westport, librarians determine when online searching should be used in a specific situation. Then, they also determine how long it should be paid for by the library and when the patron should begin to pay. As with traditional reference work, a line is drawn with each patron as to how much individual service is justified or warranted. At Westport, this is usually a halfhour of online searching or traditional reference assistance. The time limit is a guideline, not a rigid rule. The initial inquiry is free, and librarians at Westport anticipate that most information needs can be met within the allotted time. ${ }^{9}$

One may not agree with this model, espe- 
cially its pricing structure, but the basic concept is sound. As long as librarians are gatekeepers, we must determine when online searching is mandatory and when it is unnecessary.

One of the major problems with online services is choosing the most costeffective database rate structures. Harry Kibirige writes:

In some organizations utilizing services from commercial data banks, the central administration may purchase data communications services from Telenet, the technical library may use AT\&T, and the medical center may use Tymnet when accessing the same data banks. In such a situation, wastage of funds can be avoided by initiating a central data communications policy and minimizing the number of data communications vendors. ${ }^{10}$

Finally, library administrators must seek support for automation from as many sources as possible. They must look to foundations and to the government. They must be able to document their cases to assure that the library and its technologies will provide concrete benefits to the community it serves. This means lobbying and investing in grant campaigns. For those who may doubt the effectiveness of lobbying, let me cite an example provided by Fay Blake when, a few years ago, Jerry Brown, as governor of California, showed up unexpectedly at a California Library Association conference: "A University of California librarian brought to his attention the growing problem of fees for services, got his quick acknowledgement that this sounded elitist and undemocratic and his agreement to consider legislation for alternatives. Before the day was out, a proposal was in the works for the preparation of such legislation. An amendment to the California Library Services Act is under consideration providing for a stateowned online database service that would provide to public and academic libraries and to state agencies the most frequently used databases at a minimum charge."11 Although most lobbying does not achieve such immediate results, it can pay off in the long run.

A final point is that library administrators should remember that users can be effective advocates. Once the general pub- lic, particularly the university community, is convinced that new and better services are necessary and demands them as their right, half of the battle will be over.

Let us assume that we have all been wise, diligent, and first-rate grantsmen or grantswomen and that we all have automated libraries. One of our first concerns should be the acquisitions policies appropriate to a network environment. As many of us already know, libraries need to reorient themselves to a world in which collecting information is of less concern than transmitting and providing access to it.

At the 1983 IFLA conference, Maurice Line, Director General of the British Library Lending Division, explained:

More and more information will be transmitted but not recorded. Secondly, the recording of information will no longer be in the fixed forms to which we have been accustomed-the printed page, the gramaphone disc, the film-because electronic stores are amenable to change. Our attitudes to national archives of recorded knowledge will have to change; and if libraries are not to have a diminishing role as information communicators, they will have to devote less attention to storage and more to transmission. It will take us some time to adjust to the concept of recorded information as fluid and changeable. ${ }^{12}$

How does this new concept of information change our collecting policies? First, we should try to offset the price of supporting technology by canceling expensive subscriptions to rarely used and duplicative print indexes and services. A library might choose not to pay "up front" for an index that may be used once in a year and instead subscribe to an online service where payment is only required if the service is used.

Another consequence of this new orientation to collection development may be that libraries will have to stop buying in areas that are rarely used. Of course, I am not urging libraries to abandon their archival function. What I am suggesting is that the archival function be carried out collectively. For example, first, RLG libraries and, now, ARL libraries are conducting conspectus projects to compile a comprehensive, subject-based assessment of 
their members' existing collections and collecting practices. The aim is to make each library responsible for certain areas of strength. The philosophical underpinning is simple and sound: in today's world, access of information, not ownership, is the key.

There are other areas where library automation will produce net gains. The old adage "time is money" is still true, and technology saves both time and money by opening up new and more efficient lines of communication between internal departments and among various libraries. Automated libraries are also less laborintensive than libraries of the past. At first, we will save hours by freeing staff from one chore to deal with another. Eventually we will be able to reduce the size of our support staffs. The online cata$\log$, for example, will eventually eliminate the need for clerks to file cards. It will also reduce the number of staff needed for bibliographic checking since the information will be readily available online.

Until recently, technology has saved us money in the "back room," but as the number of independent users grows, there will be less and less demand for research staff. Thus, we will be saving in the "front room" as well; but, to realize these savings we will need truly "user friendly" systems. One day many patrons will be able to address reference queries directly to the online catalog or to terminals dedicated to bibliographic databases. In most cases, online searching will be more flexible and comprehensive than manual searching. Those who think users will find electronic searches too complicated and time-consuming should recall that many patrons are now overwhelmed by the enormous task of tracking down print texts, deciphering their symbols and instructions, and extracting the right facts. For these patrons, online searching may well prove a blessing. In fact, almost all of the questions we are getting on Bobcat (NYU's online catalog) are: "When will we get more records? When will we get terminals in other locations?" No one says "Let's go back to the card catalog."

By carefully managing our organizations as technology is applied, we should see savings in personnel costs. These savings could be applied, for example, to an annual charge for database searching and other new information services. What this boils down to is using the benefits of technology to pay for technology.

If we are wise and diligent, we should be able to automate our libraries with a minimum number of costly mistakes and a maximum amount of outside support. We should be able to save on the trade-off between access and acquisitions and achieve a few economies in personnel as well. Will all of this allow us to duck the question of user fees? Of course it won't.

I believe there are two answers to the user-fee question: The first, and more immediate, is to recognize that, while it appears to be an easy solution, simply passing on access charges to students and faculty, is not the best one. Instead, I propose that we pass on the problem rather than the bill. We do not determine how many books are needed by students of economics or English or advertising or law. The faculty determines that. The schools and colleges determine, for the most part, the level of services they expect from the library and, in theory, they cover the costs of these services by taxing their students. Is it really so different when databases replace books and journals? Cannot the schools, colleges, and departments establish guidelines, set access standards, and cover the cost through tuition, as they always have? The alternative, charging everyone for every service, is neither cost-efficient nor consistent with our basic philosophy. I believe we are in a good position to make our case. I have argued for years that online services should be an integral part of a library's reference department. The results have been good. Recently, NYU's Vice-President for Finance came to realize that, philosophically, computer services-including those offered by the library-are an essential educational service for the university and that students should no longer pay directly each time such services are rendered. Philosophically, at least, the point has been made.

There is a second answer to the question of costs. It lies in the uses that will be made 
of our new systems, the role our libraries can play in the knowledge industry, and the ways in which we may offset the costs of technology-not by what we save on our old operations, but by what we earn on some of our new ones.

Most studies demonstrate that academic libraries are one of the biggest customers of commercial databases. If this is the case, then we should use our clout to convince database vendors to price their services to libraries at flat or discount subscription rates rather than on a connect-hour basis. If vendors would take this first step, everyone would benefit-libraries, researchers, and vendors alike. Lower fees would translate into greater volume. Jan Egland of BRS has no argument with this. "It is preferable from our point of view," he says, "to have a smaller return from a larger number of connect hours than to rely on high return from a limited percentage of the total potential searching volume. ${ }^{\prime 13}$

Vendors can be a source of additional revenue, since there is a flip side to the library-vendor relationship. Richard Phillips Palmer writes:

For some of the services that they render, information services rely on libraries. They turn to libraries when they are engaged in research, document delivery, information-on-demand, and consulting services. ... Over half of the fee-based information services in this country belong to the Special Libraries Association in order to gain access to libraries. ${ }^{14}$

Many entrepreneurs state that user charges would not be a deterrent to their use of libraries.

It was the business side of libraries that drew the greatest attention at a conference on library budget problems held at C. W. Post last June. In my opinion, the most important contribution of the conference was its emphasis on academic libraries assuming an active role in the information industry and having off-campus users pay for it. This holds true when we talk not only of database developers and information brokers, but also of corporations who tap into the databases of special libraries such as NYU's Graduate Business Library or Real Estate Institute. If information is power in this wired world-a concept now popular in the corporate worldbusinesses must be willing to pay the price. And they are.

In short, when dealing with those who recognize and treat information as a commodity and who use it for profit, libraries must be prepared to do the same. It seems foolhardy to give information at bargain rates to those prepared to pay dearly for it and then to whine that we have no choice but to demand user fees from students and scholars.

Let's take the notion of the library's business side a bit further. If libraries are bold enough, they can do more than negotiate subscription rates from vendors or charge information brokers for library services. They can become better retailers of information. Leasing database services at subscription or discount rates, libraries could then offer search services to offcampus clients with no other access. This retailing would pose no more threat to database vendors than traditional library operations have posed to conventional publishers. Furthermore, it would secure for libraries a vital and appropriate role in the knowledge industry.

As a great many speakers at the C. W. Post conference agreed, the external marketing of online services may be the best way to solve the financial crises of academic libraries and to preserve the public's right to equitable access. If we take the initiative, develop the excess capacity of our own information services, and actively solicit more commercial users through aggressive marketing, we may see the library move naturally and effectively over the ninth wave and into the new information age. If we are going to get this transition under way, we must develop agreements with database producers and vendors. It is all very well to speculate about why we should get flat subscription rates and what we could do with them if we had them. However, we are not going to get them by complaining about how unfair the present system is or by pleading our worth as socially useful institutions.

We have a chance to get what we want, or a part of it, if we get together and flex 
some collective muscle. We know how much of their services we use and we know how much they depend on our resources. We must make sure that they know it and that we are not prepared to sit by passively and see vendors fatten while we are forced to impose user fees.

An immediate concern is the vitality of the decisions we will be making in the next few years. The quickening rate of technological change will continue. There is no turning back or holding off. If libraries are going to survive, they will have to automate, and library administrators will have to hone their management and fundraising skills. To support the costs of automating, libraries will have to use local and national networks to the fullest while protecting their legitimate interests. Libraries will also need to develop the "corporate connection." This may mean charging information brokers and retailing database services to off-campus users. A rational economic structure may include ventures with hardware and software firms, as well as involvement in the videotext market, other new technologies, and markets not yet developed.

It may seem that I am proposing the creation of something that is completely different from what libraries are today, but all that these ventures change are the support and management of libraries, not their mission. We must assume a more active role in the knowledge industry to preserve the entitlement to information and to assure free access not as a dead ideal but as a living reality.

\section{REFERENCES}

1. Ogden Nash, "The Terrible People," in Happy Days (New York: Simon \& Schuster, 1933).

2. John R.U. Page, "Economics and Politics of Information Technology: Some Trends in Its Application to Information for the Professional, " Information Technology Section, IFLA General Conference, Munich, 1983, p.6.

3. Ibid.

4. Ibid.

5. Nancy C. Kranich, "Fees for Library Service: They Are Not Inevitable!" Library Journal 105:1050 (May 1, 1980).

6. Fay M. Blake, "What's a Nice Librarian Like You Doing Behind a Cash Register?" in User Fees: A Practical Perspective, ed. Miriam Drake (Colorado: Libraries Unlimited, 1981), p. 46.

7. Lawrence J. White, "The Public Library-Free or Fee?" The New Leader 62:4 (December 17, 1979).

8. Ibid.

9. James Rice, Jr., "Fees for Online Searches: A Review of the Issue and a Discussion of Alternatives," Journal of Library Administration 3:31 (Spring 1982).

10. Harry Kibirige, The Information Dilemma: A Critical Analysis of Information Pricing and the Fees Controversy, (Westport, Conn.: Greenwood, 1983), p. 125.

11. Blake, p. 47

12. Maurice Line, "Some Possible Future Effects of Information Technology," Information Technology, Social Science Libraries, Biological and Medical Libraries Sections, IFLA General Conference, Munich, 1983, p.2-3.

13. John Brewster Smith and Sara D. Knapp, "Data Base Royalty Fees and the Growth of Online Search Services in Academic Libraries," Journal of Academic Librarianship 7:209 (September 1981).

14. Richard Phillips Palmer, "Overview of Information Industry and Fee Services by Academic Institutions," Proceedings of Conference on Fee-Based Research in College and University Libraries, C. W. Post Center of Long Island University, Greenvale, New York, June 17-18, 1982, p.9. 